\title{
Communicative and interactive culture of the modern school teacher: professional requirements, problems, risks
}

\author{
Igor Yu. Sinel'nikov ${ }^{1, *}$ \\ ${ }^{1}$ ISED RAE, Center of Social and Liberal Education, 105062, Moscow, Russia
}

\begin{abstract}
The article is dedicated to the problem of level of dialogical and communicative competence culture of a modern school teacher in Russia. The author reveals the main feature of the communicative culture of a teacher, which consists in the predominance of authoritarian, not dialogical style of communication, training and interaction. In the article problematic aspects are marked, indicating a low level of dialogic-communicative culture of a school teacher. The main risks of the current situation and ways to overcome them are formulated.
\end{abstract}

The expanding space information offers a person all the great volumes and a greater variety of information, advances ever greater demands on the human skills to work with the growing information flow. Along with the competence to search, select, interpret, evaluate information, the ability to communicate and interact with others is increasingly important. The ability to support a variety of content, form and style of communication, the ability of the civilized expression of their views, the willingness to understand and accept a different view all that are the skills, which become necessary for everyone in today's multicultural open world.

The school plays important role in the formation of communicative abilities. The school is designed to help the younger generation in the formation of skills and qualities, which are necessary for the successful socialization. Naturally the modern requirements to the professionalism of the teachers imply the possessing of skills and competencies that relate to the field of teacher communication with the students.

According to professional standards (2013), a school teacher should be able to:

- engage in dialogue with the pupils;

- generate the culture of dialogue in the pupils;

- encourage the formation of students' emotional and rational needs in communication as a process that are vital for a person;

- facilitate the formation of the ability to communicate, to promote the use of this ability and understanding its value [1].

As it can be seen, the professional requirements suggest that the modern teacher should not only generate communication skills in their pupils, but to own them perfectly.

In modern pedagogical science set of skills and competences in the field of communication is most often termed "communicative competences" or "communicative culture" of the teacher. In the last 15 years in Russia the problem of formation of pedagogical culture of communication was the subject of many dissertations: G.P.Maksimova (2000), E.I.Mychko (2002), S.L.Suvorova (2005), Z.A.Pobezhimova (2007), L.A.Auhadeeva (2008), N.V.Zhizneva (2011), Yu.A.Bazhenova (2015) and others.

Today communicative culture is accepted to be one of the main components of professional culture of the teacher. It reflects the specificity of communication with the students and helps to achieve their educational and training purposes. The main processes of communication are: perception (perception of one another), communication (transmission of information in the process of communication), interaction (interplay) [2, p.436].

In the exploring the phenomenon of communicative culture of the modern teacher the investigators note its individual aspects: technological-communicative (V.A.Mischenko, 1999), discoursive-communicative (S.L.Suvorova, 2005) and others. In our opinion, the dialogue-communicative aspect is one of the most important aspects of pedagogical communication. In order to ensure the readiness and the ability of graduates of school to be engaged in constructive dialogue with others, achieve mutual understanding, find common aims, work together to achieve the overall results, as required by the federal state educational standards [3, p.3-5], the teacher should possess willingness and ability to dialogical communication and interaction. Therefore, the professional competences of school teachers should be represented by:

- ability to understand the position of the pupil in the communication, to show interest in his personality;

Corresponding author: siu1104@mail.ru 
- ability to interpret and read the internal state of the pupil on base of the nuances of behavior;

- ability to stay on the pupil's point of view and to create an atmosphere of trust in communication with another person;

- ability to treat humorously to specific aspects of teaching;

- possession of techniques of rhetoric and means of non-verbal communication (facial expressions, gestures);

- domination of the organize actions (compared to evaluation and especially disciplining);

- dominance of democratic style of teaching [4, p.144-145].

In fact, we are talking about the willingness and ability to implement democratic style of pedagogical dialogue in which the teacher focuses on the improvement of the subjective role of the student in the interaction.

In modern science, democratic style of teaching is recognized as the only real way of organizing the cooperation of the teacher and students: it is a "core" of student-centered pedagogy. However, as it is considered to be priority in the theory, this style is realized with great difficulties in practice. The long-term observations, communication with the students, parents and teachers indicate that authoritarian stereotypes of perception of the students' position and style of interaction with them still dominate at schools, in the mind of the administrators and teachers: the position of teacher psychologically and practically is rarely used in the dialogical communication field, equal partnership and cooperation with the students [5, p.1454].

The current situation shows not only the basic feature of the interactive communicative culture of the modern Russian teachers, but the number of "problematic aspects". Let's characterize each of them.

The first aspect of the problem: school teachers often do not understand the essence of the authoritarian style of communication; they often confuse it with the persistence, adherence to principles and the strictness of the requirements with the importance of maintaining the authority of the teacher. Often the teachers justify the use of the authoritarian style of communication, referring to the unavailability of students to the new and high requirements.

The experience and science research indicate that in practice a teacher cannot completely exclude some particular methods of communication in authoritarian style. Sometimes these techniques are quite effective, especially when working with classes and individual students with relatively low level of socio-psychological and personal development. But in this case, the teacher should be aimed generally on the democratic style of communication, dialogue and cooperation with students, as only this style allows implementing the studentoriented strategy of pedagogical interaction [6, p.38].

The second aspect of the problem: the teachers often wrongly perceive an authoritarian style of teaching as a pedagogically efficient and highly productive, they assess the situation from the point of view of achieving by pupils the required educational results. In this case, a significant part of the teachers shows their commitment for "reproductive learning style" [7, p.94] whose efforts:

- are focused on the transfer of the regulated and dogmatic knowledges, are aimed to the quick and accurate reproduction of the requirements of teacher;

- are implemented mainly in the form of a monologue, the content of the material and the control of the level of its mastering are represented only on the basis of reproduction that does not admit the alternatives and accounting the views of pupils.

Despite the fact that reproductive learning style may give the expected result, however, the losses from its using are incommensurable. It is known, that in the process of reproductive learning: the memory is overloaded, but the perception, imagination, an alternative way of thinking are blocked; the fatigability of the organism is increased; the interest in teaching and, as a result, indicators of academic performance are decreased.

The third aspect of the problem: teachers often can not adequately assess the effect produced by the chosen style of communication and learning.

The conducted survey of 200 Russian teachers about their understanding the causes of conflict with pupils, revealed an interesting trend. In the rating of the 6 indicators - the authoritarianism and lack of professionalism have been recognized by teachers as the least important causes of their conflict with the students [8, p.143-144]. This trend shows the low level of teachers' critical reflection relatively implementation of their professional activities: teachers excluded from the list of factors of possible negative influence the two most important indicators - the style of communication and the level of professional competence.

The totality of these aspects of the problem allows discussing a low level communicative and interactive culture of school teachers that is manifested in all the spheres of communication with students: in the areas of perception, communication, interaction and reflection.

In this regard, teachers' commitment to the authoritarian style of communication and interaction that comes into contradiction should be considered as an important fact: on the one hand, the requirements for the professionalism of the teacher, on the other hand, the objective tendencies of development of interpersonal communication in the modern information society.

A study conducted by the Center of Social and Liberal Education of the Institute for Strategy Education Development of the Russian Academy of Education (2015), showed that the aspiration of teachers to active use of modern information technology in the educational process does not change the overall picture: the majority continues to be committed to reproductive style, to explanatory and illustrative methods of learning and communication.

Existing feature of communicative-dialogue culture and its negative manifestations provoke the preservation of "problematic situation" and the emergence of risks:

- the risk of the spontaneity of the dialogue of the teacher with the students, - it can be manifested in unconscious use of the usual or unprompted 
communication styles (often - authoritarian or anarchical / permissive) by the teacher;

- the risk of deformation of the student's personality, - it can be manifested in the formation of students' unwanted personal characteristics and qualities (inadequate self-esteem, lack of independence, passivity, aversion to dialogue, arguments, etc.).

The overcoming of the existing problems and risks is only possible by updating the teacher training system and improving their skills in additional education institutions, in universities and in schools. It is necessary to reorient the training of employees and future teachers: on the formation of a democratic style of communication; to the development of the capacity for reflection; on formation of skills of using modern communicative and interactive technologies; on the formation of the readiness to an equal partnership with the pupils.

\section{References}

1. A professional standard. The teacher (tutor, teacher). Order of the Ministry of Labour and Social Protection of the Russian Federation, October 18, 2013 №544n. Available online: URL http://www.rg.ru/2013/12/18/ pedagog-dok.html (accessed on: 21.01.2016) [In Rus]
2. L.A. Grigorovich, and T.D. Martsinkovskaya, Pedagogy and Psychology (Gardariki, Moscow, 2003) [In Rus]

3. The federal state educational standard of the secondary general education. Available online: URL http://минобрнауки.рф/документы/2365/файл/736/12. 05.17-Приказ_413.pdf (accessed on: 02.12.2015) [In Rus]

4. N.V. Bordovskaya, and A.A. Rean, Pedagogy (St. Petersburg, Peter, 2006) [In Rus]

5. I.Y. Sinelnikov, Updating the methodology of training and education in general education: problemriskological aspect. Proceedings of the International scientific and practical Internet-conference "Psychopedagogical support of modern education: challenges, problems and risks", 8-10 June 2015 (ASOU, Moscow, 2015) [In Rus]

6. V.A. Slastenin, I.F. Isaev, E.N. Shiyanov, Pedagogy, ("Academy", Moscow, 2002) [In Rus]

7. N.V. Bordovskaya, and A.A. Rean, Pedagogy (Moscow, 2006) [In Rus]

8. V.S. Sobkin, and A.S. Fomichenko, Understanding the reasons for teachers of pupils manifestations of aggression to the teacher (Institute of Sociology of Education RAO, Moscow, 2012) [In Rus] 